\title{
EXPLORING TOURIST EXPENDITURES OF THE GJIROKASTRA DISTRICT IN ALBANIA: A CLUSTER ANALYSIS
}

\author{
Irena Boboli ${ }^{1}$, Etleva Muça Dashi ${ }^{2 \bowtie}$ \\ 1"Eqerem Çabej" University of Gjirokaster, Albania \\ ${ }^{2}$ Agricultural University of Tirana, Albania
}

\begin{abstract}
Tourism expenditures are an important indicator for measuring the impact of tourism on a destination. Information taken from the micro data of tourism expenditures, together with other socio-demographic characteristics of visitors, provides important data on the tourist demand for a destination. Visitor costs in combination with other variables can be used to profile the demand for tourist goods and services in the destination area. In this paper, the daily expenses of visitors in the Gjirokastra district of Albania are analysed. The Gjirokastra district is one of the more preferred regions and attracts a considerable number of domestic and foreign visitors, because it offers a diversity tourist attractions and services. For the purposes of this study, a survey of 200 visitors was conducted. The survey results were analysed with descriptive statistics via a cluster analysis. The survey provides detailed data on the daily expenses of visitors, divided into six main categories of a typical travel budget. Through the use of data mining cluster analysis, we identified and analysed the tourists' daily expenses based on the purpose of their visit to the area of Gjirokaster.
\end{abstract}

Key words: tourism, Gjirokastra, visitor expenditures, cluster analysis, Albania

JEL codes: C88, R49, Z32

\section{INTRODUCTION}

In recent years, tourism has transformed into one of the most important sectors influencing the economic growth of Albania. Tourism initiatives have increased, with the development of alternative forms of tourism such as mountain tourism, cultural tourism, adventure tourism, among others. Tourist expenditure plays a crucial role in the growth of the economy. Today, the contribution of tourism to the economy is projected to grow to $9.3 \%$ of GDP [Ministry of Tourism and Environment 2019].

However, the earthquake of November 26, 2019 and the lockdowns arising from the COVID-19 pan- demic, in particular, have had a negative impact on the growth of tourism. The tourism sector during 2020 suffered tremendous losses, although countries with modest numbers of COVID-19 cases did attempt to attract tourists [Nientied and Shutina 2020]. The development of tourism during the pandemic has impacted the management of resources so that economic, social, and aesthetic needs can be satisfied simultaneously with the provision of life protection systems and ecological processes [Roman et al. 2020]. Public policies for regenerating tourist areas in Albania are related to specific national measures such as the vaccination of tour operators, facilitating tourism infrastructure, etc. Del Valle [2020] anticipates that the COVID-19 after- 
math will enhance new tourism consumption habits.

As a result, it is important to calculate the costs and expenditures borne by tourists during their vacation. This data will help with visitor profiling, which is an important tool in recognising target groups that is very useful in tourism and hospitality [ $\mathrm{Vu}$ et al. 2015]. Tourism expenditure is therefore a consumer choice, first between goods and services within various industries, and also between various expenditures within the tourism industry [Zheng and Zhang 2011]. The instruments determining tourist expenditures have been widely researched because they generate income and knowledge for local businesses [Mortazavi 2021].

\section{MAIN DEBATES}

Tourism is considered an important factor contributing to the economic growth of host countries, bringing benefits and profits in both the short and long term. Tourism can be seen as a sector or group of sectors that offers a collection of products, the consumers of which are tourists. Given the different type(s) of tourists, marketers hope to classify them into market segments exhibiting the same consumer behaviour and reactions to marketing activities, to make it easier to determine the common reasons for purchasing behaviour within each market segment. It then becomes possible to target market segments with specific products and bring these products to market using different methods [Bull 2002].

Marketers further differentiate between buyers and divide them into smaller segments that are fairly homogeneous in terms of need, resources, location, buying attitudes, or buying practices. The main purpose of segmentation activities is to ensure that potential and current customers can be reached more effectively and that communication, product, and service offerings can be matched to the unique needs of different consumers [De Villiers et al. 2019].

Market segmentation has a number of benefits. At the most general level, it forces organisations to take stock of where they stand and where they want to be in future. In so doing, it forces organisations to reflect on what they are particularly good at compared to competitors and make an effort to gain insights into what consumers want [Dolnicar et al. 2018]. By dividing the market into segments, marketing managers can acquire a better understanding of the needs and wants of customers [Camilleri 2017]. Furthermore, there is a specific economic interest in tourism segmentation, since different types of tourists (market segments) operate under different economic constraints and have a different economic impact as a result of their tourism activity [Bull 2002].

Tourism expenditures are related to several indicators, which determine the quantity of money spent and the type of tourists visiting different areas. So, expenditures are important since they contribute to market segmentation [Loon and Rouwendal 2017]. Understanding tourism expenditure is important because it is considered an expenditure-oriented economic activity [Mihalic, 2002]. Demand in the sector is defined as the amount of tourism goods and services that individuals want and can buy at certain prices, in a certain market and at a certain time [Lagos 2005].

Most studies on tourist expenditure are focused on microeconomic models since they are considered to be closer to theoretical economic consumer models under a global optic [Alegre and Pou 2004, Wang and Davidson 2010, Lin et al. 2015, Konstantakis et al. 2017]. Compared to studies at the macro level, micro-economic models have the advantage of closely mimicking theoretical economic consumer models and can include the diversity and heterogeneity of consumer behaviour that is often cancelled out when aggregate information is used [Kumar et al. 2018]. The main advantages in using micro data encompass the fact that such data report the expenditure of individual travellers, together with demographic, social and other characteristics that can be used to monitor (or profile) the units of analysis [Belenkiy and Riker 2013]. Tourism expenditures are influenced by a wide range of socio-demographic and economic variables, psychological variables, variables related to travel and destination and, lastly, by the level of satisfaction. A review of the literature on the level of customer satisfaction shows that it stimulates repeated visits, positive recommendations and therefore new customers, increased reputation, higher acceptance of price increases and, consequently, increased benefits in general [Disegna and Osti 2013, 2016]. 


\section{TOURISM SECTOR IN ALBANIA}

In Albania, tourism has become one of the four most important sectors of economic development, particularly in recent years since international attention has turned to the region. Referring to the strategy drafted by the Ministry of Tourism and Environment [2018]: "Albania will be recognized as an attractive, authentic and hospitable tourist destination in the Mediterranean region and Europe, based on the sustainable use of natural, cultural and historical potential for the development of high quality and diverse products, easily accessible from international markets".

The country has supported the development of tourism in its natural and cultural heritage: UNESCO sites, traditional food, beautiful beaches, rich ecosystems, rural areas, etc. The economic and social impact has begun to be felt, as almost all figures in the tourism industry show growth. Indeed, the World Travel and Tourism Economic Impact Report 2018 of the World Travel and Tourism Council [WTTC] notes that during 2017, tourism recorded a direct contribution of USD 1.12 billion, about $8.5 \%$ of GDP, which rose in 2019 to $20.5 \%$ of GDP. The contribution for 2020 was $10.6 \%$, a decrease of $51.6 \%$ compared with 2019 [WTTC 2021].

In addition to the economic impact, from a deeper perspective, the development of tourism has other effects that are social and demographic in character. Investments in tourism increase the employment potential of a large mass of the population. Tourism decentralises the economy, making possible the development of certain regions - both urban and rural - even if it is of a seasonal nature. Employment in the tourism sector, including accommodation and service structures, as well as tour operators, has reached considerable levels. An estimated 243,900 people were employed in this sector in 2019, approximately $21.3 \%$ of the total employment in the country. This number decreased in 2020 , however, to $17.5 \%$, a reduction of 20.2\% [WTTC 2021].

With the increase in foreign visitors, the goal of quality and elite investment has significantly increased. INSTAT [2020] reports that in 2019 Albania was visited by a record 6.4 million foreign tourists, an increase of $8.1 \%$ compared to 2018 and $74.4 \%$ in contrast to 2014. The number of foreign citizen arrivals to the territory of Albania in 2020 numbered 2,657,818, a decrease of $58.5 \%$ compared with 2019 [INSTAT, 2020]. Regarding foreign visits in Albania, the economic impact is estimated at around USD 2,493.3 million compared to USD 1,149.9 million in 2020 [WTTC 2021].

An important region in terms of its contribution to Albanian tourism can be found in the district of Gjirokastra, considered to be one of the most attractive destinations. It is situated in the southern part of Albania and bordered by the districts of Tepelene, Permet, Vlora, Saranda, and Greece with a total area of $1,137.34 \mathrm{~km}^{2}$. Gjirokastra is a rich tourist destination associated with a variety of natural and cultural attractions, in a small geographic area that is easily accessible to European tourists. Its historical and cultural objects and monuments, archaeological attractions and museums constitute a rich offering for the development of cultural and historical tourism in the district. There are 545 cultural monuments, of which 216 are in the first level and 229 monuments in the second level, in addition to 33 protected areas [Instituti Kombë1tar i Trashëgimisë Kulturore 2020].

There are approximately 106 natural monuments in the district, the most noteworthy being: 1) the nature reserve of Kardhiqi, with an area of 1,800 ha; 2) the Fir of Hotovë-Dangëlli National Park with an area of 1,200 ha; 3) the Natural Park of Zagoria. In May 2018, the mountain ecosystem of Zagoria was declared the "Natural Park of Zagoria", with an area of 24,590,320 ha. In July 2018, the Vjosë Zagori Valley was proposed by the Ministry of Tourism and Environment as one of the 16 priority areas for tourism development because of its high concentration of tourism products [AASF 2019]. Gjirokastra has been identified as the region with the largest number of villages included in the "100 villages" programme [AASF 2019].

\section{METHOD}

Cluster analysis is a technique or set of techniques used to group different objects (goods, persons, businesses, farms, etc.) into groups according to some clearly defined similarity, or dissimilarity criterion [Osmani 2006]. A tourism cluster is linked with the geographic concentration of interconnected com- 
panies and institutions through tourism activities [Iordache et al. 2010]. Dolnicar [2002] considers cluster analysis a tool for market segmentation. Visitor profiling and tourism segmentation help tourist organisations and destinations to identify common characteristics of visitor groups and develop marketing strategies accordingly [Hong Sun et al. 2016]. Sangpikul [2008] and Slabbert and Laurens [2011] used cluster analysis to determine tourist motivation, while Brida et al. [2010] used it to segment the host population in relation to their views on tourism policy strategies and to assess the perceptions of residents regarding the impact of cruise tourism on the local community.

Through this paper we have analysed the profile of Gjirokastra vistors according to their expenditure at museums, archeological parks, and natural attractions. The main problem in our selection was the absence of preliminary data on the visitors, so we determined the number of interviewed persons through the number of tickets sold near the tourism office in Gjirokastra. We conducted 200 random face-to-face surveys during the second part of 2020. The number of visitors was lower compared with the same period during the previous year due to COVID-19 restrictions. An important element of the study analysis relates to the manner in which the survey sample was selected. The inability to create a framework before sampling began was the reason that led to cluster selection. Cluster analysis is one type of strategy associated with data mining [Iswandhani and Muhajir 2018].

In our case, a two-stage cluster selection was made. Several points were determined during the movement of visitors in the first phase and a random selection of visitors to these points was made for the second. Half of the visitors were surveyed during the morning and the remainder in the afternoon, as there was no accurate information on the frequency of visitor schedules. Through this sampling the greatest possible involvement of groups of visitors was enabled and the best possible sample was determined.

Data processing was undertaken with Weka [Waikato Environment for Knowledge Analysis] software. We used this programme since it supports several standard data mining tasks including data pre-processing, clustering, classification, regression, visualisation, and feature selection [Aher and Lobo 2013]. The posterior mode was chosen and the division into groups was determined after data analysis.

\section{RESULTS}

To identify the visitor profile expenses we used several independent socio-demographic variables such as gender, age, education, current job and daily expenses. The dependent variable was the purpose of the trip. Table 1 shows that the majority of tourist expenses were dedicated to accommodation and food/drink, 28.04 and $28.00 \%$, respectively. In contrast, $20.86 \%$ of daily expenses were spent on local products, while transport accounted for only $12.50 \%$ of the total costs. Generally, the tourists interviewed were visiting the south of Albania and did not consider tour guides to be important for their vacation.

According to the itemised breakdown shown in Table 1, we found that most of the expenses for traditional accommodation averaged EUR 12.62; EUR 11.60 was spent on food and drink, while EUR 9.40 was allocated to local products. About EUR 4.60 was spent on transportation costs and the smallest daily expense was for guides (EUR 2.28), adventure sports (EUR 2.40), and other expenses (EUR 2.10).

Table 1. Daily average expenses

\begin{tabular}{lcc}
\hline Categories & $\begin{array}{c}\text { Average } \\
\text { (EUR) }\end{array}$ & $\begin{array}{c}\text { Total average } \\
(\%)\end{array}$ \\
\hline Accommodation & 12.62 & 28.04 \\
Food and drink & 12.60 & 28 \\
Transport & 5.60 & 12.5 \\
Guide & 2.48 & 5.5 \\
Purchase of local products & 9.40 & 20.86 \\
Other expenses & 2.30 & 5.1 \\
Total daily expenses & 45 & 100 \\
\hline
\end{tabular}

Source: [Surveys 2020].

Data mining helped specify all tourist expenses according to the clustering results as presented in Table 2. Visitors were asked about their daily expenses for all categories during their stay in Gjirokastra. The main expenses were related to traditional accommodation and food and drink. The only exception was for the small cluster corresponding to tourist expenditure 
Boboli, I., Muça, E., Dashi. (2021). Exploring tourist expenditures of the Gjirokastra district in Albania: a cluster analysis. Acta Sci. Pol. Oeconomia 20 (2), 13-20, doi: 10.22630/ASPE.2021.20.2.11

Table 2. Daily expenses in (\%)

\begin{tabular}{lcccccc}
\hline Attribute & $\begin{array}{c}\text { Cluster 0 } \\
\text { food and } \\
\text { drink }\end{array}$ & $\begin{array}{c}\text { Cluster 1 } \\
\text { adventure }\end{array}$ & $\begin{array}{c}\text { Cluster 2 } \\
\text { traditional } \\
\text { accommodation }\end{array}$ & $\begin{array}{c}\text { Cluster 3 } \\
\text { purchase of } \\
\text { local products }\end{array}$ & $\begin{array}{c}\text { Cluster 4 lo- } \\
\text { cal transport }\end{array}$ & $\begin{array}{c}\text { Cluster 5 } \\
\text { educational }\end{array}$ \\
\hline Traditional accommodation & 16.00 & 10.86 & 38.52 & 14.86 & 12.52 & 7.22 \\
Traditional food and drink & 32.20 & 20.2 & 20.16 & 11.01 & 11.24 & 5.22 \\
Local transport & 12.10 & 18.00 & 11.46 & 11.20 & 36.18 & 11.04 \\
Guide & 12.90 & 9.82 & 4.12 & 7.85 & 6.74 & 6.69 \\
Purchase of local products & 15.7 & 7.64 & 18.35 & 35.64 & 19.82 & 2.80 \\
Adventure sports & 18.00 & 30.86 & 17.80 & 9.87 & 19.13 & 4.30 \\
Education and other expenses & 15.26 & 2.83 & 13.70 & 12.62 & 19.20 & 36.40 \\
\hline
\end{tabular}

Source: [Surveys 2020].

for visits to relatives in the area, since these are not tourist visits.

Clusters from Table 2 are further explained below:

- Cluster 0 - tourist expenditure in Cluster 0 pertains to food and drinks. Among their preferences they like mostly to spend money on the typical gastronomy of the Gjirokaster region. Their expenses correspond to $32.2 \%$ of the total amount spent by tourists on food and drink. This group is mainly composed of middle-aged persons with a monthly net income of between EUR 500 and EUR 1,000. The tourists in this group spend a daily average of EUR 28.20 on food and drink - the largest part of their budget.

- Cluster 1 - tourists in Cluster 1 are categorised as adventure. Within this cluster are expenses in relation to adventure sports in the Gjirokastra region. They chose to stay one night in the accommodation facilities and the rest of their time outdoors. The Gjirokastra district offers different types of these adventures including horse-drawn carriage driving, diving in Lake Viroi and hiking, among other activities. The tourists who comprise this group are mostly young, less than 40 years old.

- Cluster 2 - tourists in Cluster 2 are those who spend money on traditional accommodation in guest houses all over the Gjirokastra region. They spend on average EUR 48,70 per day during their stay in the area. Tourists in this grouping choose to stay longer in the area and consequently spend more on accommodation.
- Cluster 3 - this grouping concerns the purchase of local products. The region of Gjirokastra is wellknown for many handmade products, even in the food sector with its traditional recipes. Handicrafts are traditional and of interest to tourists who bring a memento home. Tourists in this cluster spend on average EUR 46.70 per day. We observed from the questionnaires that this group was mostly composed of women.

- Cluster 4 - tourists in Cluster 4 pertain to local transport, which is used mainly by those who make very detailed plans. These types of tourists seek to maximise their time on vacation with a high number of activities and spend on average EUR 36.80 each day just on transportation. This group is characterised as highly educated people of medium income level who usually try to maximise their time and expenditure and visit most of the tourist attractions over a shorter time period.

- Cluster 5 - a smaller grouping, Cluster 5 concerns educational activities and expenditure is considered to be acceptable for local businesses. This group is considered to be mixed, since tourists from different categories are included such as:

- tourists with school-age children. They often visit museums and historical cities to increase their knowledge,

- highly-educated people who wish to learn more about the history of Gjirokastra,

- tourists who are interested in learning traditional production processes such as those of the stone cutter, wood cutter, beekeeper, etc. 
This cluster analysis confirms the importance of demographic variables and behavioural characteristics as important tools in the touristic market segmentation for visitors to Gjirokastra. These variables are considered to be important as noted by previous researchers examining market segmentation [Dolnicar 2002, Perdue 2004, Kazeminia et al. 2013, Camilleri 2017, De Villiers et al. 2019].

\section{CONCLUSIONS}

This paper has provided an analysis of the expenditure behaviour of visitors in the Gjirokastra district. We note that understanding tourism expenditure is important since it is related to economic activity. Our conclusion reflects that of Mihalic [2002]. The direct contribution of tourism lies in the expenditure on goods such as accommodation, transportation, and attractions. The direct effects are changes in production, which benefits the businesses that provide goods and services to tourists. The secondary effects are related to private and public investments in the area through the function of tourism. Cost-based segmentation is an important tool as it provides specific information about tourism purchasing models for managers and administrators working in the sector. Moreover, it can be used in the implementation of market strategies and in the assessment of their impact in each destination.

From the analysis of the data used in this study, six groups emerged - clusters of visitors according to the grouping of their expenses during their trip, specifically: food and drink, adventure, traditional accommodation, purchase of local products, local transport, and educational. The analysis of daily expenses shows that visitors spend in all expense categories. On an average day, visitors spend EUR 45, most of which is on accommodation, food, and buying local products. Through the segmentation of expenditure and information about the profile of visitors in the Gjirokastra region, businesses engaged in tourism benefit, enabling them to support their strategies in order to increase their competitive advantage. The local community and local government also benefit. Micro-economic models of tourist demand can be created by analysing the costs of visitors in the region in the future.

\section{REFERENCES}

Aher, S.B.,Lobo, L.M.R.J. (2013). Prediction of Course Selection in E-Learning System Using Combined Approach of Unsupervised Learning Algorithm and Association Rule. [In:] V.V Das, Y. Chaba (Eds), Mobile Communication and Power Engineering. AIM 2012. Communications in Computer and Information Science, vol. 296. Springer, Berlin, Heidelberg, https://doi. org/10.1007/978-3-642-35864-7_22

Alegre, J., Pou, L. (2004). Micro-Economic Determinants of the Probability of Tourism Consumption. Tourism Economics 10(2), 125-144.

Belenkiy, M., Riker, D. (2013). Destination choices of individual international travellers. Tourism Economics 19(5), 1099-1106.

Brida, J., Riano, E., Zapata, A. (2012). Residents' perceptions toward cruise tourism impact on a community: a factor and cluster analysis. Cuadernos de Tourismo 29, 79-107.

Bull, A. (2002). Touristiki Oikonomia. Kleidarithmos, Athens.

Camilleri, M.A. (2017). Market Segmentation, Targeting and Positioning. [In:] M.A. Camilleri (Ed.), Travel Marketing, Tourism Economics and the Airline Product: An Introduction to Theory and Practice. Springer, Cham, Switzerland, https://doi.org/10.1007/978-3-319-4984924

De Villiers, R., Tipgomut, P., Franklin, D. (2019). International Market Segmentation across Consumption and Communication Categories: Identity, Demographics and Consumer Decisions and Online Habits'. [In:] U. Ayman, A.K. Kaya, Promotion and Marketing Communications. IntechOpen, London, https://doi.org/10.5772/ intechopen 89988

Del Valle, A.S. (2020). The Tourism Industry and the Impact of Covid-19, Scenarios and Proposals'. Global Journey Consulting, Madrid. Retrieved from https://worldshoppingtourism.com/en/the-tourismindustry-and-the-impact-of-the-covid-19-scenarios-and-proposals [accessed 04.11.2020].

Disegna, M. Osti, L. (2013). The Influence of Visitors' Satisfaction on Expenditure Behaviour. BEMPS - Bozen Economics \& Management 14, 1-29.

Disegna, M., Osti, L. (2016). Tourists' expenditure behaviour: The influence of satisfaction and the dependence of spending categories. Tourism Economics 22(1), 5-30.

Dolnicar, S. (2002). A review of data-driven market segmentation in tourism. Journal of Travel \&Tourism Marketing 12(1), 1-22. 
Boboli, I., Muça, E., Dashi. (2021). Exploring tourist expenditures of the Gjirokastra district in Albania: a cluster analysis. Acta Sci. Pol. Oeconomia 20 (2), 13-20, doi: 10.22630/ASPE.2021.20.2.11

Dolnicar, S., Grün B., Leisch, F. (2018). Market Segmentation Analysis, Understanding It, Doing It, and Making It Useful. Springer, Singapore, https://doi. org/10.1007/978-981-10-8818-6

Hong Sun, R., Xing Hao, J., Chio Fong, D.K., Law, L., Yu, Y. (2016). Exploring the Expenditure-based profile of Macao Visitors: A Cluster Analysis. Association for Information Systems AIS Electronic Library (AISeL) PACIS 2016 Proceedings Pacific Asia Conference on Information Systems (PACIS). Retrieved from http://aisel. aisnet.org/pacis2016 [accessed 20.04.2021].

Institute of Statistics, INSTAT (2020). Arrivals of foreigners in Albania by purpose of travel, 2014-2018. Retrieved from http://www.instat.gov.al/en/themes/industry-tradeand-services/tourism/\#tab2 [accessed 15.05.2021].

Institute of Statistics, INSTAT (2020). The movements of foreign citizens according to the purpose travel, monthly. Retrieved from http://www.instat.gov.al/media/7948/ movem-of-citizens-december_2020.pdf [accessed 15.05.2021].

Instituti Kombëtar i Trashëgimisë Kulturore (2020). Retrieved from http://iktk.gov.al/site/pasuri-kulturore/ [accessed 01.05.2021].

Iordache, C., Ciochină, I., Asandei, M. (2010). Clusters - Tourism Activity Increase Competitiveness Support. Theoretical and Applied Economics 17, 5(546), 99-112.

Iswandhani, N., Muhajir, M. (2018). K-means cluster analysis of tourist destination in special region of Yogyakarta using spatial approach and social network analysis' Journal of Physics: Conference Series 974 012033, https:// doi.org/10.1088/1742-6596/974/1/012033

Kazeminia, A., Del Chiappa, G., Jafari, J. (2013). Seniors' Travel Constraints and Their Coping Strategies. Journal of Travel Research 54(1), 80-93, https://doi.org/10.117 7/0047287513506290

Konstantakis, K.N., Soklis, G., Michaelides, P.G. (2017). Tourism Expenditures and Crisis Transmission: A General Equilibrium GVAR Analysis with Network Theory. Annals of Tourism Research 66, 74-94.

Kumar, J., Garg, A., Fukey, L.N. (2018). In-Depth Review of Microeconomic Analysis of Business Tourist Spending. Asia-Pacific Journal of Innovation in Hospitality and Tourism, 7(2), 39-50.

Lagos, D. (2005). Touristiki Oikonomiki. Kritiki, Athina.

Lin, V.S., Mao, R., Song, H. (2015). Tourism Expenditure Patterns in China. Annals of Tourism Research 54, 100-17.

Loon, R.V., Rouwendal, J. (2017). Travel purpose and expenditure patterns in city tourism: evidence from the Amsterdam Metropolitan Area. Journal of Cultural Econom- ics 41, 109-127. https://doi.org/10.1007/s10824-0179293-1

Mihalic, T. (2002). Tourism and economic development issues. [In:] R. Sharpley, D. Telfer, Tourism and development: Concepts and issues. Channel View Publications, Clevedon.

Ministria e Turizmit dhe Mjedisit (2018). Retrieved from https://turizmi.gov.al/ 16-areas-with-priority-in-tourism [accessed 15.05.2021].

Ministry of Tourism and Environment (2019). National Strategy for Sustainable Tourism Development 20192023. Retrieved from https://turizmi.gov.al/wp-content/uploads/2019/12/National-Tourism-Strategy-20192023-EN.pdf [accessed 15.05.2021].

Ministry of Tourism and Environment (2018). National Strategy for Sustainable Tourism Development 2018-2020 .

Mortazavi, R. (2021). The relationship between visitor satisfaction, expectation and spending in a sport event. European Research on Management and Business Economics 27(1), 100132. https://doi.org/10.1016/j.iedeen.2020.10.002

Nientied, P., Shutina, D. (2020), Tourism in Transition, the Post COVID-19 Aftermath in the Western Balkans. CoPLAN Resilience Series 2. https://doi.org/10.32034/ /CP-PPRESI-P01-02.

Osmani, M. (2006). Metodat Statistikore Multivariate. Blendi, Tiranë.

Perdue, R.R. (2004). Sustainable Tourism and Stakeholder Groups: A Case Study of Colorado Ski Resort Communities. [In:] G. Crouch, I. Perdue, R. Richard, H. Timmermans, M. Uysal, Consumer Psychology of Tourism, Hospitality and Leisure, vol. 3. CABI, Wallingford, 253-264.

Programi i Mbështetjes së Agrobiznesit Shqiptar (AASF), Creative Business Solutions (CBS) (2019). Sektori i agroturizmit në Shqipëri: Potencialet për zhvillim dhe nevojat financiare, Tiranë. Retrieved from https://aasf. com.al/wp-content/uploads/2020/03/Agroturizmi-ALB. pdf [accessed 01.05.2021].

Roman, M., Niedziólka, Krasnodebski, A. (2020). Respondents' Involvement in Tourist Activities at the Time of the COVID-19 Pandemic. Sustainability 12(22), 9610, https://doi.org/10.3390/su12229610

Sangpikul, A. (2008). A factor-cluster analysis of tourist motivations: A case of U.S. senior travelers. Original Scientific Paper, 56(1), 23-40.

Slabbert, E., Laurens, M. (2011). Motivation-Based Clustering: An Empirical Study of Vizitors to Kruger National Park in South Africa. Book of Proceedings Vol. II 
International Conference on Tourism \& Management Studies-Algarve.

Vu, H.Q., Li, G., Law, R., Ye, B.H. (2015). Exploring the travel behaviours of inbound tourists to Hong Kong using geotagged photos. Tourism Management 46, 222-232.

Wang, Y., Davidson, M.C. (2010). A Review of Micro Analyses of Tourist Expenditure. Current Issues in Tourism 13(6), 507-524.

World Travel \& Tourism Council (WTTC) (2018). Econo- mic impact research. Retrieved from https:www.wttc. org-mediafilesreportseconomic-impact-researchcountries-2018walbania2018.pdf [accessed 10.05.2021].

World Travel \& Tourism Council (WTTC) (2021). Albania 2020 annual research. Retrieved from https://wttc.org/ Research/Economic-Impact [accessed 10.05.2021].

Zheng, B., Zhang, Y. (2011). Household Expenditures for Leisure Tourism in the USA, 1996 and 2006. International Journal of Tourism Research 15(2), 197-208.

\section{BADANIE WYDATKÓW TURYSTYCZNYCH W OKRĘGU GJIROKASTRA W ALBANII: ANALIZA SKUPIEŃ}

\section{STRESZCZENIE}

Wydatki na turystykę są ważnym wskaźnikiem pomiaru wpływu turystyki na destynację. Informacje o wydatkach na turystykę, wraz z innymi cechami społeczno-demograficznymi odwiedzających, dostarczają ważnych danych o popycie turystycznym na kierunki turystyczne. Koszty odwiedzających w połączeniu z innymi zmiennymi można wykorzystać do profilowania popytu na towary i usługi turystyczne w obszarze docelowym. W niniejszym artykule przeanalizowano dzienne wydatki odwiedzających albański okręg Gjirokastra. Okręg ten jest jednym z bardziej preferowanych regionów i przyciąga znaczną liczbę turystów krajowych i zagranicznych, ponieważ oferuje różnorodność atrakcji turystycznych i usług. Na potrzeby tego badania przeprowadzono ankietę wśród 200 odwiedzających. Wyniki ankiety zostały przeanalizowane za pomocą statystyk opisowych z wykorzystaniem analizy skupień. Ankieta dostarcza szczegółowych danych o dziennych wydatkach odwiedzających, podzielonych na sześć głównych kategorii typowego budżetu podróżnego. Dzięki wykorzystaniu analizy skupień zidentyfikowano i przeanalizowano dzienne wydatki turystów na podstawie celu ich wizyty w rejonie Gjirokastra.

Słowa kluczowe: turystyka, Gjirokastra, wydatki turystów, analiza skupień, Albania 